\title{
PENERAPAN STANDAR ASUHAN KEPERAWATAN JIWA NERS UNTUK MENURUNKAN INTENSITAS WAHAM PASIEN SKIZOFRENIA
}

\author{
Fallon Victoryna $^{1 *}$, Ice Yulia Wardani ${ }^{1}$, Fauziah $^{2}$ \\ ${ }^{1}$ Program Studi Profesi Ners, Fakultas Ilmu Keperawatan Universitas Indonesia, Pondok Cina, Kecamatan Beji, \\ Kota Depok, Jawa Barat, Indonesia 16424 \\ ${ }^{2}$ Rumah Sakit Dr. Marzoeki Mahdi Bogor, Jl. DR. Sumeru No.114, Menteng, Kec. Bogor Bar., Kota Bogor, \\ Jawa Barat, Indonesia 16111 \\ *fallonvictoryna@yahoo.co.id
}

\begin{abstract}
ABSTRAK
Skizofrenia merupakan gangguan jiwa yang kompleks. Gejala yang paling sering ditemui adalah waham. Waham dialami oleh $60 \%$ penderita skizofrenia dengan intensitas yang lebih berat dibandingkan dengan gangguan jiwa yang lain. Pasien waham memiliki kecenderungan untuk memunculkan reaksi agresif karena adanya upaya konfrontasi dari lingkungan terkait pemikiran dan keyakinannya yang tidak realistis. Kecenderungan tersebut merupakan efek dari besarnya intensitas waham yang dialami pasien. Salah satu cara untuk mengontrol perilaku agresif tersebut adalah melalui latihan deeskalasi. Penanganan yang komprehensif perlu diberikan berdasarkan standar asuhan keperawatan (SAK) jiwa dan pemberian latihan deeskalasi secara adekuat pada pasien dengan gangguan proses pikir waham. Penulisan karya ilmiah akhir ners ini bertujuan untuk menggambarkan penerapan asuhan keperawatan jiwa ners dan latihan deeskalasi terhadap agresifitas pasien untuk menurunkan intensitas waham. Metode yang dilakukan adalah berupa analisis kasus pada pasien yang dirawat di RS Dr. H. Marzoeki Mahdi Bogor, dengan diagnosis keperawatan gangguan proses pikir waham kebesaran. Hasil dari pemberian intervensi selama 8 hari adalah pasien mengalami penurunan intensitas waham dari skor 16 dengan kategori berat menjadi skor 11 dengan kategori sedang. Kesimpulannya terdapat penurunan intensitas waham dengan menerapkan standar asuhan keperawatan jiwa ners dan latihan deeskalasi terhadap agresifitas pada pasien skizofrenia.
\end{abstract}

Kata kunci: deeskalasi, skizofrenia, standar asuhan keperawatan, waham

\section{APPLICATION OFPSYCHIATRIC NURSING CARE STANDARDS TO REDUCE THE INTENSITY OF DELUTION SCHIZOPHRENIA}

\begin{abstract}
Schizophrenia is a complex mental disorder. The most common symptom is delusions. Estimated $60 \%$ of schizophrenics have more severe intensity compared to other mental disorders with the same diagnose. Patients with delusions tend to elicit aggressive reactions because of attempts at confrontation from the environment related to unrealistic thoughts and beliefs. The tendency is the effect of the amount of delusions experienced by patients. One way to control aggressive behavior is through de-escalation exercises. Comprehensive treatment needs to be given based on psychiatric nursing care standards and the provision of adequate de-escalation exercises to patients with delusional thought processes. The writing of this final scientific work aims to illustrate the application of nursing care and de-escalation exercises to the aggressiveness of patients to reduce the intensity of delusions. The method used is a case analysis in patients treated at Dr. H. Marzoeki Mahdi Bogor, with a nursing diagnosis of oversized thought processes. The result of giving generalist therapy for 8 days is that the patient experienced a decrease in delusions intensity from a score of 16 with a severe category to a score of 11 with a moderate category. In conclusion, there is a decrease in the intensity of delusions by applying psychiatric nursing care standards and de-escalation training on aggressiveness in schizophrenic patients.
\end{abstract}

Keywords: de-escalation, delution, psychiatricnursing care, schizophrenia

\section{PENDAHULUAN}

Masalah kesehatan jiwa menjadi ancaman yang sangat berat karena adanya perbedaan perspektif terutama dalam konteks kesehatan.
Banyak orang yang masih menganggap masalah kesehatan jiwa bukan sebagai penyakit, padahal kesehatan jiwa sama halnya dengan kesehatan fisik, jika tidak diatasi 
gangguan kejiwaan dapat mengancam kehidupan seseorang. Menurut Our World in data of mental health pada tahun 2017 diperkirakan terdapat 970 juta orang di seluruh dunia mengalami gangguan jiwa, jumlah terbesar dengan masalah kecemasan sekitar $3,76 \%$, depresi $3,44 \%$, bipolar $0,6 \%$, dan skizofrenia 0,25\% (Ritchie, Roser, 2019). Di Indonesia, data Riskesdas (2018) menunjukkan prevalensi rumah tangga dengan ART gangguan jiwa skizofrenia/psikosis sebesar 7/1000 dengan cakupan pengobatan 84,9\%. Sementara itu, prevalensi gangguan mental emosional pada penduduk berumur $>15$ tahun sebesar 9,8\%. Angka jni meningkat dibandingkan tahun 2013 yaitu sebesar 6\% (Kemkes RI, 2019).

Salah satu gangguan jiwa berat yang paling banyak terjadi adalah skizofrenia. Skizofrenia merupakan gangguan jiwa yang kompleks, karena penyakit ini mempengaruhi esensi identitas otak dan fungsi paling kompleks yang dimediasi oleh otak (Weinberger \& Harrison, 2011). Townsend (2015), menjelaskan bahwa skizofrenia adalah gangguan neurobiologis yang dapat mengakibatkan seseorang mengalami gangguan kognitif, persepsi, emosi, perilaku dan sosialisasi. Perjalanan penyakit skizofrenia sangat heterogen. Pada fase akut, gejala positif lebih dominan menonjol. Gejala yang paling sering ditemui itu adalah waham. Hasil penelitian menunjukkan lebih dari $60 \%$ penderita skizofrenia sering mengalami kekambuhan waham atau memiliki waham yang menetap dengan intensitas waham yang lebih berat dibandingkan dengan gangguan jiwa yang lain. Meskipun setelah melewati fase akut, kerentanan skizofrenia yang mengalami waham dapat terjadi secara menetap selama beberapa tahun (Harrow., Mac, Donald., Angus., et al, 1995).

Waham adalah keyakinan yang salah yang didasarkan oleh kesimpulan yang salah tentang realita eksternal dan dipertahankan dengan kuat (Keliat, B. A., Hamid, A. Y. S., Putri, Y. S. E., Daulima, N. H. C., dkk, 2019). Waham merupakan gangguan dimana penderitanya memiliki rasa realita yang berkurang atau terdistorsi dan tidak dapat membedakan yang nyata dan yang tidak nyata (Videbeck, 2011). Pemberian intervensi keperawatan jiwa pada pasien dengan waham berfokus pada orientasi realita, menstabilkan proses pikir, dan keamanan (Townsend, 2015).
Dalam beberapa penelitian dijelaskan bahwa orientasi realita dapat meningkatkan fungsi perilaku. Pasien perlu dikembalikan pada realita bahwa hal-hal yang dikemukakan tidak berdasarkan fakta dan belum dapat diterima orang lain dengan tidak mendukung ataupun membantah waham (Keliat, Hamid, Putri, Daulima, 2019; Patton, 2006). Tidak jarang dalam proses ini pasien mendapatkan konfrontasi dari lingkungan terkait pemikiran dan keyakinannya yang tidak realistis (Dudley \& John, 1997). Hal tersebut akan memicu agresifitas pasien waham. Reaksi agresif ini merupakan efek dari besarnya intensitas waham yang dialami pasien. Haddock (1999) dalam Erawati, Keliat, dan Daulima (2014), menjelaskan intensitas waham dimanifestasikan melalui respon kognitif, afektif dan perilaku. Respon kognitif terkait dengan frekuensi pasien berfikir tentang waham, waktu dalam memikirkan waham, dan tingkat keyakinan terhadap waham. Respon afektif meliputi jumlah respon berupa perasaan ketidaknyamanan dari pemikiran waham dan intensitas dari respon tersebut. Respon perilaku berupa gangguan dalam kehidupan akibat dari pemikiran waham tersebut (Erawati, 2013; Shives, 2012).Salah satu cara untuk mengontrol perilaku agresif dari pasien waham yaitu melampiaskan kemaraham dengan aman melalui latihan deeskalasi secara verbal maupun tertulis (Hallett \& Dickens, 2017).

Teknik deeskalasi merupakan intervensi nonspesifik yang direkomendasikan untuk pengelolaan kekerasan dan agresi dalam kesehatan jiwa. Teknik ini mengembangkan teknik psikososial disaat perilaku pasien dalam keadaan yang tidak tenang, dan mengembalikan pasien menjadi lebih tenang atau memberikan umpan balik dengan harapan pasien kembali menjadi individu yang tenang (Price, Baker, Bee, \& Lovell, 2015). Berdasarkan penelitian yang dilakukan oleh Indrono, W., Caturini (2012), yaitu implementasi teknik deeskalasi pada pasien dengan perilaku kekerasan memberikan pengaruh yang signifikan terhadap kontrol emosi dan penurunan respon marah. Penelitian lain, menyebutkan metode ini dapat dijadikan sebagai salah satu sarana katarsis dan media self-help bagi pasien untuk mengekspresikan emosi dan perasaan marahnya (Fikri, 2012).

Penanganan yang komprehensif perlu dilakukan berupa pemberian tindakan keperawatan berdasarkan standar asuhan 
keperawatan (SAK) jiwa dan penerapan latihan deeskalasi terhadap agresifitas pasien dengan gangguan proses pikir waham. Tindakan keperawatan yang diberikan dengan adekuat dapat meningkatkan kemampuan kognitif, psikomotor dan afektif pasien secara lebih baik, sehingga diharapkan intensitas waham yang dialami pasien dapat menurun. Berdasarkan hal tersebut, maka penulis tertarik untuk memberikan intervensi asuhan keperawatan ners dan latihan deeskalasi pada pasien skizofrenia untuk mengetahui sejauh mana pengaruhnya terhadap penurunan intensitas waham pasien di ruangan Srikandi RS. Dr. H. Marzoeki Mahdi Bogor.

\section{METODE}

Penelitian ini merupakan studi kasus untuk menganalisis intervensi standar asuhan keperawatan jiwa dan latihan deeskalasi terhadap agresifitas pasien skizofrenia untuk menurunkan intensitas waham di RS Dr. H. Marzoeki Mahdi Bogor. Intervensi ini diberikan selama delapan hari berturut-turut. Evaluasi terhadap intensitas waham dilakukan melalui wawancara dan observasi dengan menggunakan instrument Psychotic Symptom Rating Scales (PSYRATS). Instrument ini terdiri dari 6 pernyataan meliputi kognitif, afektif, perilaku. Kognitif terkait dengan frekuensi pasien berfikir tentang waham, waktu dalam memikirkan waham, serta tingkat keyakinan terhadap waham. Afektif meliputi jumlah respon berupa perasaan ketidaknyamanan dari pemikiran waham dan intensitas dari respon tersebut dan perilaku berupa gangguan dalam kehidupan akibat dari pemikiran waham (E. Erawati, 2013; Shives, 2012). Instrumen ini dikembangkan oleh Haddoch (1999). Dalam setiap item pernyataan, disediakaan 5 pilihan jawaban, yang disesuaikan dengan tujuan yang akan dinilai dari setiap item pernyataannya. Hasil skoring berada dalam rentang skor antara 0-24 dengan kategori: intensitas ringan (skor 0-6), intensitas sedang (skor 7-12), intensitas berat (skor 13-18), intensitas sangat berat (skor 1924). Hasil skoring bernilai baik jika semakin menurun nilai yang diperoleh yang berarti semakin menurun intensitas waham yang muncul pada pasien.

Adapun ilustri kasus pada penelitan ini sebagai berikut: Ny. E yang berusia 40tahun. Pada tanggal 22 Oktober 2019 di bawa ke RSMM oleh keluarga karena saat dirumah pasien gelisah dan mengatakan hal-hal yang tidak rasional. Pasien juga marah-marah saat dinasehati, bicara kasar dan tidak sesuai, menyerang orang lain, merusak alat-alat rumah tangga dan sulit tidur. Pasien diketahui mempunyai masalah kejiwaan sejak tahun 2011. Pasien pernah menjalani pengobatan di Medan, terakhir tahun 2014, putus obat dan tidak pernah kontrol lagi sejak \pm 5 tahun. Pasien mengatakan sudah sembuh dan tidak perlu minum obat lagi.

Pengkajian pada 25 Oktober 2019, klien tampak bingung, sorot mata tajam, berjalan mondar-mandir, saat diajak berinteraksi pasien tampak jengkel, nada suara tinggi dan bicara kasar. Pasien juga menyalahkan orang lain terhadap kondisi yang dialaminya, menyangkal sakit dan mengungkapkan keinginan untuk pulang. Pasien mengatakan dalam dirinya terdapat 3 jiwa dalam satu tubuh (tritunggal) yaitu Eva, Evi, dan Ipah. Masing-masing jiwa ini melakukan tugas penting untuk mensejahterakan bangsa. Pasien juga mengatakan dalam dirinya terdapat kekuatan khusus karena dirinya adalah hasil reinkarnasi dari roh-roh suci, dan mendapatkan kekuatan dari roh kudus untuk memberikan kebaikan bagi umat manusia.

Implementasi keperawatan telah dilakukan sesuai dengan rencana keperawatan yang dibuat. Tindakan keperawatan diberikan terhadap semua masalah keperawatan, dengan masalah utama yaitu gangguan proses pikir: waham kebesaran, yaitu : membina hubungan saling percaya, mengkaji perasaan yang muncul secara berulang dalam pikiran pasien, mengidentifikasi stressor pencetus waham, membantu pasien dalam mengidentifikasi wahamnya, membantu pasien mengidentifikasi konsekuensi dari wahamnya, membantu pasien melakukan teknik distraksi dalam menghentikan pikiran yang terpusat pada wahamnya, dan membantu pasien dalam memanfaatkan obat dengan baik. Implementasi latihan deeskalasi dilakukan dalam menurunkan agresifitas pasien.

\section{HASIL}

Pada analisis kasus ini, dilakukan evaluasi intensitas waham pada hari ke-1 dan ke-8 perawatan. 
Tabel 1.

Penilaian intensitaswaham $(\mathrm{n}=16)$

\begin{tabular}{ccl}
\hline Intensitas waham & Hari ke-1 & Hari ke-8 \\
\hline Kognitif & 8 & 6 \\
Afektif & 5 & 4 \\
Perilaku & 3 & 1 \\
\hline
\end{tabular}

Kemampuan pasien dalam menurunkan intensitas waham cukup banyak perkembangan walaupun belum optimal. Evaluasi penilaian intensitas waham dilakukan pada hari kedelapan. Intensitas waham mengalami perubahan, dari 6 pernyataan, terdapat 3 pernyataan yang mengalami perubahan signifikan, yaitu item no 2 dengan pernyataan waktu berfikir tentang waham, awalnya pasien mengatakan memikirkan keyakinan waham selama kurang lebih 1 jam, namun setelah dilakukan intervensi berubah dengan mengatakan memikirkan keyakinan tersebut selama beberapa menit. Pernyataan selanjutnya adalah item no 3 , di awal pasien mengatakan keyakinan terhadap wahamnya sangat kuat 5099\%, namun pada evaluasi akhir jawaban pasien berubah dengan mengungkapkan ada keraguan antara yakin dan tidak 10-49\%. Pernyataan lain yaitu item no 4, sebelum dilakukan intervensi kenyakinan waham yang dirasakan menyebabkan kondisi distress dan 50-99\% terjadi pada beberapa kesempatan setiap keyakinan itu muncul. Namun setelah evaluasi akhir kondisi ini berkurang menjadi < $50 \%$ terjadi pada beberapa kesempatan/kejadian sehari-hari. Kesimpulan evaluasi akhir didapatkan total skor 11, yang berarti intensitas waham dalam kategori sedang. Berdasarkan hal tersebut dapat dikatakan bahwa intensitas waham pasien mengalami penurunan.

\section{PEMBAHASAN}

Pasien berusia 40 tahun, diketahui mempunyai riwayat gangguan jiwa sejak tahun 2011 atau pada saat usia 32 tahun. Menurut Elvira, S. D., Hadisukanto (2017), gejala penyakit skizofrenia dapat muncul pada usia remaja akhir atau usia dewasa muda, awitan pada perempuan terjadi dalam rentang usia 25-35 tahun. Manfred Bleuler (1943) dalam Weinberger, D. R., Harrison (2011), menemukan bahwa $15-17 \%$ pasien skizofrenia memiliki onset setelah usia 40 tahun. Pada usia tersebut pasien memasuki tahapan perkembangan usia dewasa. Masa dewasa adalah masa dimana seseorang memiliki tuntutan terhadap pencapaian aktualisasi diri baik dari diri sendiri, keluarga dan lingkungan.
Di usia dewasa seseorang juga dikatakan matang secara kognitif, emosi dan perilaku. Jika terjadi kegagalan dalam tahap ini maka individu akan sulit menjalankan tuntutan perkembangan usia tersebut sehingga berdampak pada terjadinya gangguan jiwa (Stuart, 2013 ; Townsend, 2015).

Pasien diketahui menjalani perawatan dan pengobatan terakhir tahun 2014, kemudian putus obat dan tidak pernah kontrol sejak \pm 5 tahun. Pasien merasa sudah sembuh dan mengatakan tidak perlu minum obat lagi. Hal ini disebabkan karena kemampuan pasien yang tidak baik dalam mengenali penyakit yang di deritanya, pasien juga tidak mampu dalam mengenal gejala dan dampak yang timbul dari penyakit yang dialami terhadap kehidupannya. Keadaaan ini lebih dikenal dengan istilah insight. Dalam penelitian yang dilakukan oleh Mohamed et al. (2009), dikatakan bahwa ketidakpatuhan dalam pengobatan dianggap bahwa pasien mempunyai insight yang buruk. Pada kondisi seperti ini proses pengobatan akan sulit dilakukan, pasien akan menolak untuk minum obat dan kontrol kepelayanan kesehatan meskipun dilakukan dengan paksa.

\section{Mengkaji Perasaan yang Muncul Secara Berulang dalam Pikiran Pasien}

Pada intervensi ini difokuskan untuk mengidentifikasi tentang waham yang dirasakan pasien yaitu meliputi tanda dan gejala yang dimunculkan, perasaan dan pemikiran waham. Pasien dapat menceritakan pemikiran/ide-ide dan perasaan yang muncul secara berulang dalam pikirannya. Pasien mengatakan dalam dirinya ada 3 jiwa dalam satu tubuh (tritunggal) yaitu Eva, Evi, dan Ipah. Pasien mengungkapkan hal-hal yang tidak realistis, seperti "saya hasil reinkarnasi dari roh-roh suci, dan mendapatkan kekuatan dari roh kudus untuk mensejahterakan bangsa”. Dalam kasus Ny. E, tanda dan gejala yang tampak yaitu pasien mudah tersinggung dan marah jika hal yang disampaikannya dibantah. Isi pembicaraan pasien lama-lama inkoheren. Hal tesebut sesuai dengan penjelasan Keliat, Hamid, Putri, Daulima, (2019), terkait tanda dan gejala waham yaitu 
mudah tersinggung, marah, inkoheren, dan perilaku seperti isi wahamnya

\section{Mengidentifikasi Stressor PencetusWaham}

Pasien menjelaskan tentang kejadian traumatis yang menimbulkan rasa takut, ansietas dan perasaan tidak dihargai dalam kehidupannya. Pasien juga mengungkapkan kebutuhan dan harapannya yang belum terpenuhi. Selama interaksi pasien juga banyak mengeluhkan halhal tekait konsep dirinya. Salah satu stressor pencetus waham adalah harga diri rendah, hal tersebut didukung oleh penelitian yang dilakukan oleh Warman, Lysaker, Luedtke, \& Martin, (2010), yang menyatakan individu yang memiliki delusi yang tinggi memiliki harga diri yang rendah. Dijelaskan bahwa terdapat hubungan yang signifikan antara harga diri yang rendah dan tingkat kepercayaan terkait dengan gangguan pikiran/ waham.

\section{Membantu Pasien dalam Mengidentifikasi Waham}

Pada awal proses identifikasi diketahui waham yang dialami masih sangat kuat, dan pasien belum mampu dalam mengatasinya. Pasien juga belum mampu membedakan situasi nyata dan situasi yang dipersepsikan salah oleh pasien. Hal tersebut terlihat dari hasil pengukuran intensitas waham menggunakan instrument PSYRATS dengan skor 16 yang berarti intensitas waham dalam kategori berat. Setelah dilakukan intervensi, intensitas waham berkurang menjadi skor 11 yang berada pada kategori sedang. Berdasarkan instrumen PSYRATS semakin rendah skor intensitas waham menandakan hasil yang semakin baik (Erawati, 2013). Perubahan intensitas waham yang dialami pasien diidentifikasi melalui respon kognitif dimana frekuensi pasien berfikir tentang wahamnya setiap hari sekali, waktu dalam memikirkan waham selama lebih kurang 1 jam, dan tingkat keyakinan terhadap waham 50-99\%; respon afektif meliputi jumlah respon berupa perasaan ketidaknyamanan dari pemikiran waham 50-99\% terjadi dalam beberapa kesempatan setiap keyakinan itu muncul dan menimbulkan distress sedang; respon perilaku berupa gangguan minimal dalam kehidupan akibat dari pemikiran waham, tetapi pasien masih mampu menjalin hubungan sosial serta mampu mempertahankan kemandirian tanpa dukungan (Erawati, 2013)

\section{Membantu Pasien Melakukan Teknik Distraksi dalam Menghentikan Pikiran yang Terpusat pada Waham}

Salah satu cara yang dilakukan dalam menghentikan pikiran terpusat pada waham adalah membantu pasien dalam mengorientasikan realita secara bertahap. DalamVarcarolis (2014), dikatakan bahwa penerapan orientasi realita memperhatikan dimensi waktu, tempat dan orang. Dalam intervensi keperawatan yang diberikan orientasi realita difokuskan terhadap hal tersebut. Keefektifan terhadap orientasi realita terkait dengan waktu yang konsisten (Stuart, 2013). Penelitian yang dilakukan oleh Patton (2006), menyebutkan bahwa terdapat peningkatan terhadap tingkat orientasi realita pada tindakan yang dilakukan secara konsisten.

\section{Membantu Pasien dalam Memanfaatkan Obat dengan Baik.}

Pada intervensi ini diskusi dilakukan lebih lama, karena pasien menolak mengonsumsi obat. Pasien mengatakan dirinya tidak sakit dan merasa tidak membutuhkan obat, pasien juga mengungkapkan perasaan curiga terhadap obat yang diberikan. Pendekatan yang dilakukan adalah menjelaskan mengenai manfaat obat dan kerugian tidak minum obat, pasien juga dijelaskan mengenai pengobatan dengan prinsip 8 benar (pasien, obat, dosis, waktu, cara pemberian, dokumentasi, tanggal kadaluarsa). Dinicola\& Matteo (1992) dalam Pardede, Keliat \& Wardani (2013) menyebutkan ada beberapa cara untuk menghadapi klien yang mengalami ketidakpatuhan minum obat antara lain: menumbuhkan kepatuhan dengan mengembangkan tujuan kepatuhan, mengembangkan strategi untuk merubah perilaku dan mempertahankannya, mengembangkan kognitif, dan dukungan sosial. Kepatuhan terkait dengan pemaksaan, kesesuaian atas ketidakpatuhan dan perawatan diri untuk sebuah aliansi terapeutik dengan menyediakan interaksi terhadap klien (Pardede, Keliat, \& Wardani, 2013).

Pada hari pertama rawatan, pasien tidak dapat diarahkan, mengatakan dirinya mampu mensejahterakan bangsa, merasa tidak sakit dan tidak perlu dirawat. Pasien tampak marah dan bersikap arogan, nada suara tinggi, mata melotot dan tampak mengepalkan tangan. Situasi tersebut menggambarkan tanda-tanda risiko perilaku agresifitas pada pasien, sebagai 
dampak intensitas waham yang meningkat. Pada saat intensitas waham pasien dalam kategori berat, terdapat konfrontasi dari lingkungan (misalnya dari pasien lain) terhadap waham pasien sehingga menyebabkan munculnya perilaku agresifitas tersebut. Dalam Keliat, Hamid, Putri, Daulima (2019), dijelaskan bahwa tidak boleh memunculkan konfrontasi atau membantah waham. Dalam mengatasi situasi tersebut intervensi yang dilakukan adalah latihan deeskalasi.

Beberapa teknik deeskalasi dilakukan yaitu teknik komunikasi verbal seperti bicara dengan tenang, suara lembut dan menghindari pertentangan. Kemudian melakukan kontrol lingkungan dengan membawa pasien kekamarnya, ruangan yang stimulasi rendah, tenang/bebas dari kebisingan dan menyuruh pasien duduk. Selanjutnya melakukan eksplorasi terhadap perasaan pasien dan menjadi pendengar yang aktif hingga pasien menjadi individu yang tenang dan agresifitas menurun. Memfasilitasi pasien dalam mencurahkan isi hati dan pikiran dalam bentuk cerita dapat dilakukan secara verbal maupun tertulis. Beberapa topik yang dibahas adalah mengenai keluarga, hobi/aktivitas yang disukai, aktifitas yang biasa dilakukan, harapan dan keinginan realistis yang ingin dipenuhi. Latihan deeskalasi ini dilakukan setiap hari dengan lama interaksi antara 30-40 menit. Hasil evaluasi yang didapat pasien mampu mengungkapkan ide-ide dan perasaan yang muncul secara asertif, pasien mampu menyebutkan kejadian sesuai urutan waktu, pasien mampu mengungkapkan harapan atau kebutuhan realistis yaitu harapan bisa menjadi ibu yang baik untuk anaknya, pasien mampu melakukan aktivitas sesuai dengan minatnya yang dapat mengalihkan fokus pasien dari wahamnya seperti mengikuti kegiatan rehabilitasi, kegiatan TAK, senam, kegiatan seni/musik. Latihan deeskalasi dilakukan sebagai intervensi tahap awal terhadap respon emosional untuk mencegah perilaku agresi yang dimunculkan pasien (Hallett \& Dickens, 2017). Intervensi latihan deeskalasi dijadikan sebagai intervensi untuk membantu membangun aliansi terapeutik positif dengan pasien, meningkatkan kolaborasi aktif pasien dalam proses perawatan dan mengurangi episode agresif pasien (Du et al., 2017).
Pemberian asuhan keperawatan pada Ny. E dilakukan sesuai standar asuhan keperawatan jiwa, tetapi terdapat hambatan dalam penatalaksanannya, yaitu ketika intensitas waham pasien yang dalam kategori berat, pasien memunculkan respon yang dominan marah. Perlu banyak waktu yang diperlukan untuk menunggu pasien dalam kondisi yang lebih tenang. Selain itu, pasien juga mempunyai keinginan pulang yang tinggi, hal tersebut dibuktikan dengan keputusan untuk pulang atas permintaan sendiri dan melanjutkan pengobatan dengan kontrol ke poliklinik psikiatri. Hal tersebut juga merupakan salah satu hambatan dimana belum optimalnya pemberian intervensi yang dilakukan. Pada evaluasi akhir sebelum pasien pulang, penurunan tingkat intensitas waham dalam kategori sedang sudah dicapai, tetapi hal tersebut tidak diikuti dengan peningkatan kemampuan pasien dalam mengenali penyakit yang di deritanya, pasien masih mengungkapkan keraguannya terhadap penyakit yang dialaminya. Hal ini dapat menjadi ancaman karena dapat berpotensi pasien tidak mengikuti program terapi yang diberikan, ketidakpatuhan terhadap pengobatan terkait pada ketidakmampuan pasien dalam mengenali penyakit yang dideritanya (Mohamed et al., 2009). Kemungkinan terjadi relapse dengan gejala lain yang lebihparah.

Alternatif dalam mengatasi masalah pasien yang belum dapat diselesaikan adalah dengan mengoptimalkan intervensi keperawatan keluarga, kelompok dan komunitas. Disebutkan dalam Dour et al (2014), bahwa dukungan keluarga merupakan agen perubahan dalam proses penyembuhan. Sehingga dapat dikatakan intervensi yang diberikan pada keluarga sangat penting dalam mendukung proses keberhasilan perawatan pasien selama di rumah. Hasil penelitian tersebut dapat dijadikan acuan bagi perawat untuk melibatkan keluarga dalam proses keperawatan yang akan diberikan. Tindakan keperawatan yang dapat diberikan pada keluarga bertujuan agar keluarga mampu merawat pasien di rumah. Tindakan keperawatan yang dilakukan adalah mengkaji mengenai masalah yang dirasakan keluarga dalam merawat pasien, mejelaskan pengertian waham, tanda dan gejala waham, serta proses terjadinya waham yang dialami pasien. Mendiskusikan cara merawat pasien waham dan memutuskan cara merawat yang sesuai dengan kondisi pasien, menjelaskan tanda dan gejala yang memerlukan rujukan 
segera serta melakukan follow up kepelayanan kesehatan secara teratur (Keliat, Hamid, Putri, Daulima, 2019).

\section{SIMPULAN}

Pasien Ny. E berusia 40 tahun dengan diagnosis keperawatan gangguan proses pikir waham: kebesaran dengan karakteristik pasien mengatakan bahwa dalam dirinya terdapat tiga jiwa dalam satu tubuh yang merupakan hasil reinkarnasi jiwa-jiwa suci yang mampu mensejahterakan bangsa. Intensitas waham berat berpotensi untuk menyebabkan munculnya perilaku agresifitas, hal ini dapat distimulus oleh lingkungan sekitar pasien (misalnya dari pasien lain). Tindakan keperawatan pada pasien waham, dilakukan sesuai intensitas waham. Pada waham dengan intensitas berat maka dilakukan tindakan deeskalasi, sedangkan untuk waham dengan intensitas sedang hingga tingan dapat dilakukan dengan penerapan standar asuhan keperawatan jiwa ners. Evaluasi dari penerapan standar asuhan keperawatan jiwa dan latihan deeskalasi yang dilakukan selama delapan hari masa perawatan adalah terdapat penurunan skor intensitas waham, dari skor 16 (kategori intensitas waham berat) menjadi 11 (kategori intensitas waham sedang). Hal tersebut menunjukkan respon yang baik terhadap intervensi yang diberikan.

\section{DAFTAR PUSTAKA}

Cheung, P., Schweitzer, I., Crowley, K., \& Tuckwell, V. (1997). Violence in schizophrenia: role of hallucinations and delusions, 26, 181-190.

Du, M., Wang, X., Yin, S., Shu, W., Hao, R., Zhao, S., Xia, J. (2017). De-escalation techniques for psychosis-induced aggression or agitation. Cochrane Database ofSystematic Reviews 2017. China: Published by John Wiley \& Sons, Ltd. 2. https://doi.org/10.1002/14651858.CD00 9922.pub2.www.cochranelibrary.com

Dudley, R. E. J., \& John, C. H. (1997). The effect of self-referent material on the reasoning of people with delusions, $575-584$.

Erawati, E. (2013). pengaruh terapi metakognitif terhadap intensitas waham dan kemampuan metakognitif pada klien skizofrenia di rsj prof. dr. soeroyo magelang. universitas indonesia.

Elvira, S. D., Hadisukanto, G. (2017). Buku Ajar Psikiatri (Vol. Edisi ketiga). Jakarta: Badan Penerbit Fakultas Kedokteran Universitas Indonesia

Erawati, E., Keliat, B. A., \& Daulima, N. H. C. (2014). The validation of the Indonesian version of psychotic symptoms ratings scale ( PSYRATS ), the Indonesian version of cognitive bias questionnaire for psychosis ( CBQP ) and metacognitive ability questionnaire ( MAQ ), 3(2), 97100.https://doi.org/10.14419/ijans.v3i2.3 132

Fikri, H. T. (2012). Pengaruh menulis pengalaman emosional dalam terapi ekspresif terhadap emosi marah pada remaja. Humanitas, IX(2), 103-121. Retrieved from https://media.neliti.com/media/publicati ons/24580-ID-pengaruh-menulispengalaman-emosional-dalam-terapiekspresif-terhadap-emosi-mara.pdf

Hallett, N., \& Dickens, L. (2017). Deescalation of aggressive behaviour in healthcare settings: Concept analysis. International Journal of Nursing Studies, 75(June), 1020.https://doi.org/10.1016/j.ijnurstu.201 7.07 .003

Harrow., Mac, Donald., Angus., et al. (1995). Vulnarability to delution over time in schizophrenia and affective disorder. Schizophrenia Bulletin, 95-109.

Herdman, T. H., Kamitsuru, S. (2018). NANDA-I Diagnosisi Keperawatan Definisi dan Klasifikasi 2018-2020. Jakarta: Penerbit Buku Kedokteran EGC.

Indrono, W., Caturini, E.
IMPLEMENTASI TEKNIK
ESKALASI DE-
PENURUNAN RESPON MARAH
KLIEN DENGAN PERILAKU
KEKERASAN Wahyu Indrono 1,
Endang Caturini 2. Jurnal Terpadu Ilmu
Kesehatan, 2, 77-83.


Keliat, B. A., Hamid, A. Y. S., Putri, Y. S. E., Daulima, N. H. C., dkk. (2019). Asuhan Keperawatan Jiwa. Jakarta: Penerbit Buku Kedokteran EGC.

Kemkes RI. (2019, Maret 01). Perlu Kepedulian untuk Kendalikan Masalah Kesehatan Jiwa. Retrieved from Kementerian Kesehatan Republik Indonesia:https://www.depkes.go.id/arti cle/view/19030400005/perlu-

kepedulian-untuk-kendalikan-masalahkesehatan-jiwa.html

Mohamed, S., Rosenheck, R., Mcevoy, J., Swartz, M., Stroup, S., \& Lieberman, J. A. (2009). Cross-sectional and Longitudinal Relationships Between Insight and Attitudes Toward Medication and Clinical Outcomes in Chronic Schizophrenia, 35(2), 336-346. https://doi.org/10.1093/schbul/sbn067

Patton, D. (2006). Reality orientation: its use and effectiveness within older person mental health care. Journal of Clinical Nursing, 15, 1440-1449. https://doi.org/10.1111/j.1365

2702.2005.01450.x

Price, O., Baker, J., Bee, P., \& Lovell, K. (2015). Learning and performance outcomes of mental health staff training in de-escalation techniques for the management of violence and aggression. The British Journal of Psychiatry, 447455.https://doi.org/10.1192/bjp.bp.114.1 44576

Ritchie, H., Roser, M. (2019). Mental Health. Retrieved from Published online at OurWorldInData.org: https://ourworldindata.org/mentalhealth'

Riskesdas. (2018). HASIL UTAMA RISKESDAS 2018. Jakarta.

Shives, L. R. (2012). Basic Concepts of Psychiatric-Mental Heatlth Nursing (Eighth Edi). Philadelphia,: Lippincott Williams \& Wilkins. Copyright.

Stuart, G. W. (2013). Principles and Pratice of Psychiatric Nursing (10th Ed). St. Louis, Missouri: Elsevier Mosby Inc.

Townsend, M. C. (2015). Psychiatric Mental Health Nursing Concepts of Care in Evidence-Based Practice (Sixth Edit). Philadelphia: F.A Davis Company.

Videbeck, S. L. (2011). Psychiatric-Mental Health Nursing (Fifth Edit). Wolters Kluwer Health | Lippincott Williams \& Wilkins.

Warman, D. M., Lysaker, P. H., Luedtke, B., \& Martin, J. M. (2010). Self-Esteem and Delusion Proneness. The Journal of Nervous and Mental Disease, 198(6), 455457.https://doi.org/10.1097/NMD.0b $013 \mathrm{e} 3181 \mathrm{e} 086 \mathrm{c} 5$

Weinberger, D. R \& Harrison, P. J. (2011). Schizophrenia (Third Edit). USA: Blackwell Publishing Ltd.

Yusuf, Ah., Fitryasari, R., Nihayati, H. E. (2015). Buku Ajar Keperawatan Kesehatan Jiwa. Jakarta: Penerbit Salemba Medika. 